\title{
The latest US Supreme Court decisions on contraception, transgender discrimination, more
}

\author{
Abortion, contraception, gay and transgender discrimination, \\ and the ACA (again!). Here's what every ObGyn should know \\ about the most recent decisions of the Supreme Court.
}

Steven R. Smith, MS, JD, and Joseph S. Sanfilippo, MD, MBA

IN THIS ARTICLE

\section{Abortion}

decisions

page 39

\section{ACA and \\ contraception \\ access}

page 40

Employment discrimination ruling

page 42
(1)

he 2019-2020 term of the US Supreme Court was remarkable by any standard. An extraordinary number of important cases made it "a buffet of blockbusters." $^{1}$

We look first at several cases that will be of particular interest to ObGyns. Then we look briefly at a number of other important cases that affect the medical profession as a whole and the direction of the country (see "Other significant US Supreme Court decisions”), and finally we conclude with an analysis of this term and a forecast for the next.

We chose cases in which specialty organizations, such as the American College of

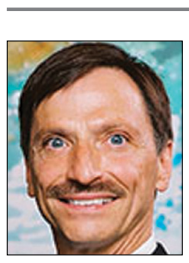

Mr. Smith is Professor Emeritus and Dean Emeritus at California Western School of Law, San Diego, California.

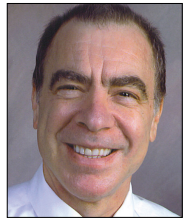

Dr. Sanfilippo is Professor, Department of Obstetrics, Gynecology, and Reproductive Sciences, University of Pittsburgh, and Academic Division Director, Reproductive Endocrinology and Infertility, Magee-Womens Hospital, Pittsburgh, Pennsylvania. He also serves on the OBG MANAGEMENT Board of Editors.

The authors report no financial relationships relevant to this article.

doi: $10.12788 /$ obgm.0037
Obstetricians and Gynecologists (ACOG), or organized medicine (the American Medical Association [AMA], the Association of American Medical Colleges [AAMC], or the American Hospital Association [AHA]), took a special interest by filing "amicus curiae" (friend of the court) briefs with the Supreme Court. These briefs are filed by an organization or person who is not a party to the case but who may have important information to convey to the Court. Because these briefs represent a significant commitment of money, time, and effort, they are usually not undertaken lightly.

\section{Decisions concerning abortion \\ June v Russo}

Decided June 29, 2020, June $v$ Russo involved a Louisiana statute that required abortion providers have "active admitting privileges at a hospital" within 30 miles of where the abortion is performed. ${ }^{2}$ The Court decided a case in 2016 (from Texas) that involved almost the same statutory provision, so it might seem like an easy ruling. ${ }^{3}$ But Justice Kennedy (the deciding vote in 2016) has been replaced by Justice Gorsuch, so the outcome was uncertain. It was a difficult case, with a total of 5 opinions covering 138 pages and a "surprise" from the Chief Justice.

The Court, in a 5-4 decision, struck down the Louisiana law, but there was no 
majority opinion. Four justices in the plurality emphasized that the Louisiana law (like the Texas law) substantially burdened the right to abortion without any corresponding benefit to the health of the women seeking abortions. (Under earlier Court precedents, "undue burdens" on abortion are unconstitutional. ${ }^{4}$ ) Justice Breyer noted that the state could not present even one example in which a woman would have had better treatment if her doctor had admitting privileges. For a variety of reasons, admitting privileges were cumbersome for abortion providers to obtain; therefore, enforcing the law had little or no benefit, but significant risk of reduced availability of abortion services.

In June $v$ Russo, Chief Justice Roberts literally became the "swing vote" - the fifth vote to strike down the Louisiana law. In 2016, he had voted the other way-to uphold essentially the same law (in Texas) that he struck down here. He attributed his switch to precedent (the general obligation of courts to follow prior decisions). He disagreed with the earlier decision, but felt bound by it.

This should be the end of the abortion provider "hospital privileges requirements" that a number of states have passed. States seeking to nibble away at abortion rights will undoubtedly look elsewhere. Beyond that, it is difficult, from this case, to discern the future of abortion rights.

ACOG was the lead in amicus briefs urging the Court to strike down the Louisiana law. ACOG (with others) was one of only a handful of organizations filing a brief urging the Court to agree to hear the case. ${ }^{5}$ When the Court did agree to hear the case ("granted certiorari"), ACOG and a number of other medical organizations filed a formal amicus brief on the merits of the case. ${ }^{6}$ The brief made 2 arguments: First, that this case was essentially decided in Whole Woman's Health in 2016 (the Texas case) and, second, that "an admitting privileges requirement is not medically necessary" and "clinicians who provide abortions are unable to obtain admitting privileges for reasons unrelated to their ability to safely and competently perform abortions." Justice Breyer cited the ACOG brief twice.

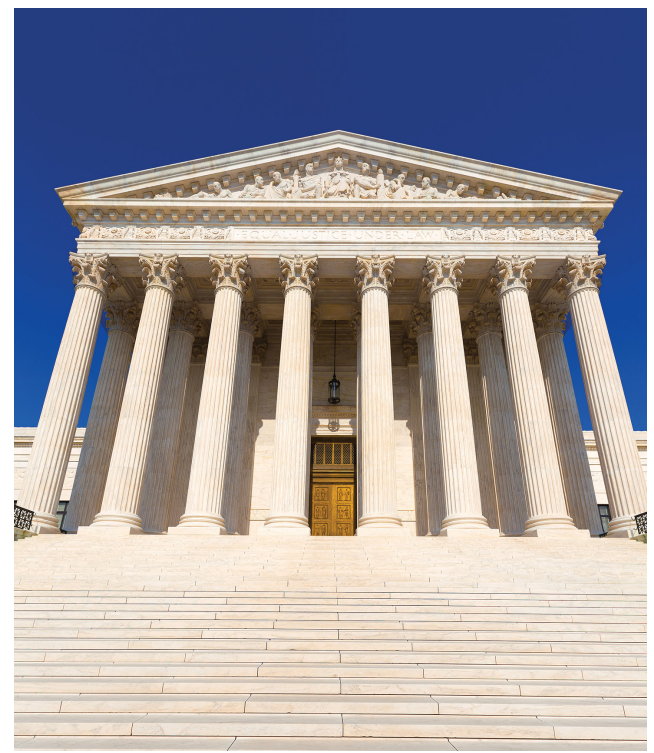

The American Association of Pro-Life Obstetricians and Gynecologists also filed an amicus brief. ${ }^{7}$ The brief was directed solely at arguing that ACOG was not presenting reliable science. It summarized, "The American College of Obstetricians and Gynecologists has always presented itself to the Court as a source of objective medical knowledge. However, when it comes to abortion, the College today is primarily a pro-abortion political advocacy organization." That brief concluded that the "Court should read ACOG's amicus brief not as an authoritative recitation of settled science, but as a partisan advocacy paper on behalf of a mere subset of American obstetricians and gynecologists."

The Association of American Physicians and Surgeons (which should not be confused with the "National Board of Physicians and Surgeons") also filed an amicus brief. The brief argued, "Abortion, like other outpatient surgical procedures, sometimes results in patient hospitalization. Requiring abortion providers to maintain admitting privileges will improve communication between physicians in the transfer of patients to the hospital and allow them to participate in the care of their patients while in the hospital, in line with their ethical duty to ensure their patients' continuity of care." ${ }^{8}$ $\overline{\text { FAST }}$

TRACK

In June, SCOTUS struck down a state law requiring abortion providers to have admitting privileges at a hospital within 30 miles 
FAST

TRACK

SCOTUS upheld

the religious

exemption for

contraception

coverage in

the $A C A$

\section{Ultrasonography requirement for abortion}

In another abortion case, the Court was asked to review a Kentucky abortion statute requiring that an ultrasound image be shown to the woman as part of informed consent for an abortion. ${ }^{9}$ ACOG filed an amicus brief in favor of a review, but the Court declined to hear the case. ${ }^{10,11}$

\section{Contraception considerations}

The Affordable Care Act (ACA) has an ambiguous provision regarding no-cost "preventive care and screenings" for women. The ACA does not, however, specify contraceptive coverage. ${ }^{12}$ Several departments and the Health Resources and Services Administration (collectively referred to as "HRSA") interpreted the provision to include contraception, but from the start there were religious objections. HRSA eventually provided an exemption regarding contraception for employers (nonprofits and for-profits with no publicly traded components) that had "sincerely held moral" objections to providing forms of contraceptive coverage. That regulation was again before the Court this term in Little Sisters of the Poor Saints Peter and Paul Home $v$ Pennsylvania. ${ }^{13}$

In a 7-2 decision, the Court held that the ACA gave HRSA authority to adopt regulations related to the undefined term "preventive care." Therefore, it found that HRSA could exempt those with religious objections from participation in providing contraceptive coverage. ACOG and other medical groups filed an amicus brief arguing that contraception is an essential preventive service. "Contraception not only helps to prevent unintended pregnancy, but also helps to protect the health and well-being of women and their children." ${ }^{14}$ It was cited only by Justice Ginsburg in her dissent. ${ }^{15}$

\section{Deferred Action for Childhood Arrivals (DACA)}

The AAMC, ACOG, AMA, and many other organizations filed an amicus brief ${ }^{16}$ in
Department of Homeland Security $v$ Regents of University of California. ${ }^{17}$ The case raised the question of whether a decision to end the DACA program followed the appropriate administrative procedures. In 2012, the Obama administration issued a "memorandum" establishing DACA (without congressional approval or formal rulemaking). A lower court decision barring implementation of DACA was upheld by the Supreme Court in 2016 on a $4-4$ vote. ${ }^{18}$ In 2017 , the Trump administration moved to end DACA.

In a 5-4 decision, the Court held that the explanation for ending DACA was inadequate, and violated the Administrative Procedures Act, so DACA could continue until the administration redid the repeal, following the proper procedures. The decision of the Court dealt solely with the process by which the rescission took place-there was general agreement that the administration had the right to rescind it if the procedure (with legitimate reasons) was proper.

The brief for the medical groups argued that the failure of the regulation to consider "reliance interests" would have especially difficult consequences in the medical fields. It noted, "At this moment, an estimated 27,000 health care workers and support staff depend on DACA for their authorization to work in the United States. Among those 27,000 are nurses, dentists, pharmacists, physician assistants, home health aides, technicians, and others. The number also includes nearly 200 medical students, medical residents, and physicians who depend on DACA for their eligibility to practice medicine." ${ }^{16}$ The brief was not cited by the Court, but the reliance interest the brief spoke about was an important part of the case.

\section{Employment discrimination against gay and transgender employees}

Federal law ("Title VII") makes it illegal for an employer to "discriminate against any individual because of race, color, religion, sex, or national origin." ${ }^{19}$ The question this term was whether discrimination based on sexual 


\section{Other significant US Supreme Court decisions}

The Court heard and ruled on a large number of other significant cases that will have consequences for many years to come. Highlights include:

- In 2 cases involving subpoenas for the President's personal records, the Court suggested some balance between "nobody is above the law" and not unnecessarily hectoring or interfering with fulfilling the office of President. The Court held that Congress may subpoena a President's personal and family records, while the President is still in office. ${ }^{1}$ It instructed lower courts to assess whether the papers are necessary, the subpoena is limited in scope, there is legitimate legislative purpose, whether the burden it imposes on the President is reasonable, and whether the subpoena would unduly interfere with the ability to do the work required as President.

- Similarly, local (state) grand juries may subpoena such personal records, but the President will have the opportunity to raise specific objections to the subpoenas - undue burden, bad faith, or overbreadth. In addition, the respect owed to the office should inform the conduct regarding the subpoena. ${ }^{2}$

- The Court upheld a federal law that prohibits most robocalls. ${ }^{3}$ It struck down an amendment that allowed robocalls made to collect debts owed to or guaranteed by the federal government.

- The Court held that a single-director federal agency, whose director cannot be removed by the President (at will), violates the Constitution. ${ }^{4}$ The Consumer Financial Protection Bureau (created by the Dodd-Frank law) has such a single, no-removal director and that will have to be modified.

- The Court held that the eastern half of Oklahoma (including Tulsa) is part of a Creek Nation reservation. ${ }^{5}$ This was a question of criminal law jurisdiction, not property ownership. The practical effect is that for crimes involving Native Americans, serious crimes will have to be tried in federal court, while lesser crimes may be tried in tribal courts.

- The Court determined that it was unconstitutional for a state program providing tuition assistance to parents who send their children to private schools, to prohibit students attending religious private schools from participating in the program. That is a burden on the "free exercise" of religion. ${ }^{6}$

- The Court considered whether there can be civil liability for damages caused by a federal official in the United States harming a foreign national in another country. In this case, a border patrol agent standing in the US shot and killed a Mexican juvenile who was just across the border in Mexico. ${ }^{7}$ The issue was whether the parents of the Mexican national could sue the US officials for damages. The Court declined to expand liability to include those injured outside the US. Ultimately, the Court was reluctant to impose liability because this liability is not authorized by Congress.

- In a COVID-19 religion case, the Court refused to stop the enforcement of a governor's COVID-19 order that allowed churches to operate with $<100$ attendees or $25 \%$ occupancy (whichever was lower). ${ }^{8}$ Meanwhile, businesses, malls, and stores were allowed to reopen without these stringent limitations. The church objected that greater burdens were placed on religion than secular activity. The Court denied the church's request for an injunction.

- The Court unanimously held that a state may punish or remove a "faithless elector." Electors cast votes on behalf of their states in the Electoral College-where Presidents are technically selected. Electors are generally pledged to vote for the winner of a state's vote for President. A few have violated that pledge and voted for someone else. As a practical matter, that could cause real disruption, and the Court upheld state laws that take action against these "faithless" electors. ${ }^{9}$

- Several days after the Court had officially adjourned for the term, it received several petitions to delay the execution of federal prisoners. One case was based on the method of execution (use of pentobarbital), ${ }^{10}$ and another was based on the claim that a prisoner had become so mentally incompetent that it was improper to execute him. ${ }^{11}$ The Court turned down these appeals, allowing the executions to proceed. These were the first federal government executions in 17 years.

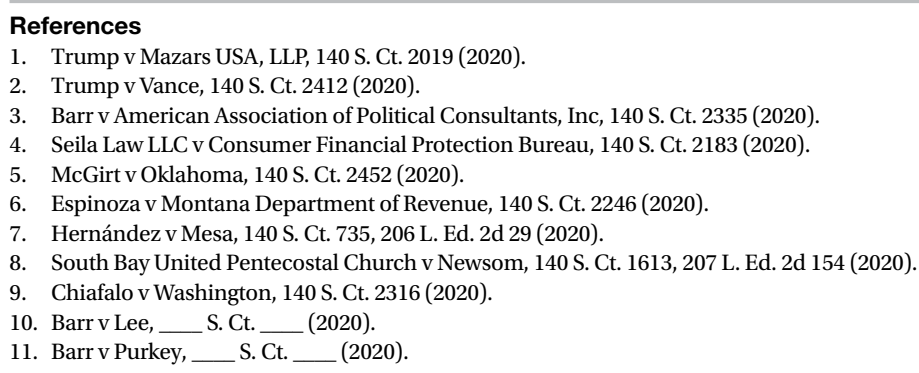


$\overline{\text { FAST }}$

TRACK

SCOTUS

interpreted

"sex" in Title VII

(which makes it

illegal for employers

to discriminate

against race, color,

religion, sex,

or national origin)

as including sexual

orientation and

sexual identity orientation or sexual identity is within the statute's meaning of "sex." By a 6-3 majority, the Court held that Title VII applies both to orientation and identity. (This was an interpretation of the statute, not a broad constitutional ruling.)

The majority reasoned that "it is impossible to discriminate against a person for being homosexual or transgender without discriminating against that individual based on sex. Consider, for example, an employer with 2 employees, both of whom are attracted to men." If the employer fires the gay employee, "the employer discriminates against him for traits or actions it tolerates in his female colleague." $^{20}$

AMA and a number of other medical organizations filed an amicus brief in the case. ${ }^{21}$ The core of the argument of the brief was, "Employment discrimination against transgender people frustrates the treatment of gender dysphoria by preventing transgender individuals from living openly in accordance with their true gender identity and impeding access to needed medical care. Experiencing discrimination in one of the most important aspects of adult lifeemployment-makes it nearly impossible to live in full congruence with one's gender identity. The fear of facing such discrimination alone can prompt transgender individuals to hide their gender identity, directly thwarting the goal of social transition.... Lack of treatment, in turn, increases the rate of negative mental health outcomes, substance abuse, and suicide." The brief was not cited in the opinions in the case.

This decision is likely to have great impact on many aspects of American life. In the employment area, it is now a matter of course that employers may not discriminate based on orientation or identity in any employment decisions including hiring, firing, compensation, fringe benefits, etc. Harassment based on identity or orientation may similarly be an employment law violation. The decision also likely means that giving employment preferences to gay employees would now be as illegal as would be giving preferences to straight employees. (Limited exceptions, notably to some religious organization employees, are not included in antidiscrimination laws. ${ }^{22}$

The importance of the decision goes well beyond employment, however. More than 100 federal statutes are in place that prohibit "discrimination because of sex." It is now likely that these statutes will be interpreted as prohibiting discrimination related to sexual orientation and identification.

\section{Additional cases of interest HIV/AIDS International Program}

A major US program fighting HIV/AIDS worldwide-the United States Leadership Against HIV/AIDS, Tuberculosis, and Malaria Act (aka the Leadership Act) - has provided billions of dollars to agencies abroad. ${ }^{23}$ Nongovernmental organizations (NGOs) receiving funds under the program must agree to have a "policy explicitly opposing prostitution and sex trafficking" (known as the "Policy Requirement"). Some grant recipients in foreign countries, generally affiliates of US NGOs, do not want to have such a policy and challenged the policy requirement as a violation of First Amendment right of free speech. The Court held that it is a well-settled principle that "foreign citizens outside US territory do not possess rights under the US Constitution." ${ }^{24}$ Nor do organizations become entitled to such rights as a result of an affiliation with US organizations. This decision means that foreign organizations are free not to have the required policies, but they will be ineligible for funds under the Leadership Act.

\section{ACA government debts edition}

The ACA was before the Court, yet again. To encourage private insurers to participate in online health insurance exchanges, the ACA provided that the federal government would share in insurance company losses for 3 years. ${ }^{25}$ The Act, however, did not appropriate any money for these "risk corridors," and insurance companies lost $\$ 12$ billion.

Congress (after the 2010 election) prohibited any appropriated funds from being used to pay insurance companies for their risk corridor losses. Four insurance companies 


\section{RBG: The woman, the legacy}

Ruth Bader Ginsburg, as a law student, law professor, lawyer, judge, and justice, was a leading advocate for the rights of women. There were only a few women in law school when she attended, but she graduated tied for first in her class. Although she found it difficult to be hired as a lawyer, as a law professor and lawyer she helped map a strategy to expand legal rights for women, arguing 6 cases before the Supreme Court and winning 5 of them. She served as a federal appeals court judge and then was appointed to the Supreme Court in 1993. She was the second woman to serve on the Court.

As a justice, she was known during much of her tenure on the Court as the leader of the liberal justices, although her jurisprudence was more complex than that simple statement. She was always a strong advocate for the rights of women (and equal rights of men) during her time on the Court. She was a very clear writer; her opinions were direct and easy to understand. She was also fast-she routinely had the record of announcing opinions faster than any of the other current justices. She was 87 when she passed away, having served on the Court for 27 years.

Justice Ginsburg was also something of a cultural phenomenon. In later years she was sometimes known as "the Notorious RBG." Books, movies, songs, and even workout videos were made about her. In groups she seemed almost shy, but she was thoughtful, kind, and funny (sometimes wickedly so). The outpouring of affection and sympathy at her death was a symbol of the place she held in America. She loved the opera, a passion she shared with her friend, Justice Antonin Scalia. Despite their considerable disagreements on legal matters, Justices Ginsburg and Scalia were close friends. They attended opera with one another, and their families usually spent New Year's Eves together. They were the 2 most recent justices to pass away while serving on the Court. sued the United States, seeking reimbursements for their losses. This term the Court held that the government must pay for their losses under the ACA. ${ }^{26}$ The Court said that Congress could have expressly repealed the risk corridor obligation (in the appropriation bill), but instead had only prohibited the expenditure of the money, which the Court said did not amount to an implied repeal of the obligation. We will see that ACA will be back before the Court again next term in California v Texas (discussed below).

\section{Child custody and international abduction}

The Hague Convention on the Civil Aspects of International Child Abduction (to which the United States is a party) provides that the courts of the country where the child has "habitual residence" have jurisdiction to decide custody. ${ }^{27}$ If a parent takes the child to another country, that country is obligated to return the child to the country of "habitual residence."

This term the Court was called upon to define "habitual residence." The Court held that determining habitual residence depends on the "totality of the circumstances," and that "locating a child's home is a fact-driven inquiry," and that "courts must be sensitive to the unique circumstances of the case and informed by common sense." ${ }^{28}$ An exception to the Convention's obligation to return a child to the country of habitual residence is where "there is a grave risk that [the] return would expose the child to physical or psychological harm or otherwise place the child in an intolerable situation." ${ }^{29}$ Who the parent is can affect many aspects of legal authority over the child, including consent to medical care, and the right to receive information concerning care.

\section{Analysis of the term}

The term began October 7, 2019, and adjourned July 9, 2020, somewhat later than usual because of coronavirus disease 2019 (COVID-19). During the term, the Court decided 60 cases, including 53 "signed" merit opinions after oral argument-the lowest number of decided cases in many years. ${ }^{30}$ Of those 60 cases, 22 (35\%) were unanimous, and $13(22 \%)$ resulted in a $5-4$ split. ${ }^{30}$ Tenyear averages are $48 \%$ unanimous and $20 \%$ with 5-4 decisions. ${ }^{30}$

Chief Justice Roberts was the central focus of the term. He presided over the impeachment trial of President Trump in the Senate early in the term. He also presided over the Court's accommodations of the COVID-19 pandemic. He is the "median," or "swing," justice. He was in the majority in 12 of the 13 cases with 5-4 decisions. ${ }^{30}$ He was in the majority in $97 \%$ of all cases and in $95 \%$ of "divided cases" - the highest of any of the justices this term. ${ }^{30}$ In some of the most critical decisions, Chief 
Justice Roberts sided with the "liberal" wing, including on cases concerning abortion, gay and transgender employment, DACA, and 2 Presidential subpoena cases. More often (in 9 of the 5-4 decisions), however, he sided with the more conservative justices. ${ }^{30}$ Justice Kavanaugh agreed with Chief Justice Roberts most often (in 93\% of all cases). ${ }^{30}$ Among the others, these justices agreed with each other $90 \%$ or more of the time: Justices Ginsburg and Breyer (93\%), Justices Alito and Thomas (92\%), and Justices Breyer and Kagan (90\%). ${ }^{30}$

\section{COVID-19 and the Court}

Some of the biggest news of the term came not from the law, but from medicine in the form of COVID-19. The Court was in the process of preparing a final period of important arguments when, on March 16, it announced that it was postponing further arguments. The Court rescheduled 10 oral arguments that were held by telephone (other cases were held over to the next term). The phone arguments, during the first 2 weeks of May, necessitated a change in format. Each justice was called on (in order of seniority) by the Chief Justice to ask questions. This was in contrast to the free-for-all questions that usually characterize in-person arguments. These arguments were broadcast livesomething that had never been done before. Public access was, on balance, a good thing. There were a couple failures to unmute, and there was "the flush heard round the world" in the middle of one argument, but otherwise the arguments went off with few hitches. ${ }^{31}$

\section{Looking ahead}

By the end of the term, no justice had announced an intention to retire from the Court. At least 2 justices were hospitalized during the term-Justice Ginsburg was hospitalized twice for gallbladder-related issues. Following the end of the term, she announced a recurrence of pancreatic cancer; she is receiving chemotherapy (gemcitabine). Chief Justice Roberts was briefly hospitalized for a minor injury.

The next term (called the "October 2020 Term") will begin on October 5, 2020. Most are assuming that it will be telephonic. The Court already has taken a number of cases. The constitutionality of the individual mandate (coverage) in the ACA will once again be before the Court, and that already has produced a flood of amicus briefs from healthrelated organizations. ${ }^{32}$

Among other upcoming issues are cases related to the sentencing of juveniles to life in prison without the possibility of parole, state regulation of pharmacy benefit managers, a face-off between Google and Oracle on software copyrights, and arbitration. In addition, the next term will include a return of some of the issues we saw this term, with more on robocalls, religious freedom and Catholic charities, and immigration and removal cases.
References

1. Liptak A. In a term full of major cases, the Supreme Court tacked to the center. The New York Times. July 10, 2020.

2. June Medical Services LLC v Russo, 591 US 140 S. Ct. 2103, 2112 (2020).

3. Whole Woman's Health v Hellerstedt, 579 US _ (2016).

4. Planned Parenthood of Southeastern PA v Casey, 505 US 833, 874 (1992).

5. Brief of the American College of Obstetricians and Gynecologists, the American Academy of Family Physicians, the American Academy of Pediatrics, the American College of Nurse-Midwives, the American College of Osteopathic Obstetricians and Gynecologists, the American College of Physicians, the American Society for Reproductive Medicine, the National Association of Nurse Practitioners in Women's Health, the North American Society for Pediatric and Adolescent Gynecology, and the Society for Maternal-Fetal Medicine Amici Curiae In Support of Petitioners, June Medical Services $v$ Russo. May 20, 2019. https://www.supremecourt.gov /DocketPDF/18/18-1323/100434/20190520175434029 _18-1323\%20ACOG\%20et\%20al.\%20cert.\%20amicus\%20 brief.pdf. Accessed August 31, 2020.
6. Brief of Amici Curiae American College of Obstetricians and Gynecologists, American Medical Association, American Academy of Family Physicians, American Academy of Nursing, American Academy of Pediatrics, American College of Nurse-Midwives, American College of Osteopathic Obstetricians and Gynecologists, American College of Physicians, American Osteopathic Association, American Public Health Association, American Society for Reproductive Medicine, North American Society for Pediatric and Adolescent Gynecology, Society for MaternalFetal Medicine, and the Society of Ob/Gyn Hospitalists, In Support of June Medical Services, June Medical Services $v$ Russo. December 2, 2019. https://www.supremecourt.gov /DocketPDF/18/18-1323/124091/20191202145531124 _18-1323\%2018-1460\%20tsac\%20American\%20College\%20 of\%20Obstetricians\%20and\%20Gynecologists\%20et\%20 al.pdf [https://perma.cc/8T8V-4D6S]. Accessed August 31, 2020.

7. Brief of Amicus Curiae American Association of Pro-Life Obstetricians and Gynecologists InSupport of [Russo] Louisiana Department of Health and Hospitals, June Medical Services $v$ Russo. December 27, 2019. https://www.supremecourt. 
gov/DocketPDF/18/18-1323/126927/20191227154424488 AAPLOG\%20Amicus\%20Brief.pdf. Accessed August 31, 2020.

8. Brief of Association of American Physicians and Surgeons as Amicus Curiae in Support of Respondent-CrossPetitioner, June Medical Services v Russo 2. December 27,2019 . https://www.supremecourt.gov/DocketPDF/18 /18-1323/126828/20191227104605915_18-1323\%20-1460\%20 bsac\%20AAPS--PDFA.pdf. Accessed August 31, 2020.

9. Ky. Rev. Stat. \$311.727(2)

10. Brief for the American College of Obstetricians and Gynecologists, the American Medical Association, the North American Society for Pediatric and Adolescent Gynecology, the American College of Osteopathic Obstetricians and Gynecologists, and the American Academy of Family Physicians Amici Curiae Supporting Petitioners, EMW Women's Surgical Center $v$ Meier. October 28, 2019. https://www.supremecourt.gov/DocketPDF/19/19-417 /120550/20191028184956458_19-417\%20ACOG\%20et\%20 al.\%20-\%20cert.\%20amicus\%20brief.pdf. Accessed August 31, 2020.

11. EMW Women's Surgical Center, PSC v Meier, 140 S. Ct. 655 (2019).

12. Codified at 26 U. S. C. $\$ 5000 \mathrm{~A}(\mathrm{f})(2) ; \S \S 4980 \mathrm{H}(\mathrm{a})$, (c)(2) requires employers to provide women with "preventive care and screenings" without "any cost sharing requirements."

13. Little Sisters of the Poor Saints Peter and Paul Home v Pennsylvania, 140 S. Ct. 2367 (2020).

14. Brief of Amici Curiae American College of Obstetricians and Gynecologists, American Nurses Association, American Academy of Nursing, Physicians for Reproductive Health, and Nurses for Sexual and Reproductive Health, In Support of Respondents and Affirmance, Little Sisters of the Poor Saints Peter and Paul Home $v$ Pennsylvania. April 8, 2020, https://www.supremecourt.gov/DocketPDF /19/19-431/141177/20200408152340136_19-431\%20and\%20 19-454\%20Amici\%20Curiae.pdf. Accessed August 31, 2020.

15. Little Sisters of the Poor Saints Peter and Paul Home $v$ Pennsylvania, 140 S. Ct. 2367, 2400-12 (2020).

16. Brief for the Association of American Medical Colleges (and more than 30 other organizations, including the American Medical Association, and the American College of Obstetricians and Gynecologists) Amici Curiae, In Support of Respondents,
Department of Homeland Security $v$ Regents of University of California. October 4, 2019. https://www.supremecourt.gov /DocketPDF/18/18-587/118129/20191004130646281 _Brief\%20for\%20AAMC\%20et\%20al\%20Supporting\%20 Respondents.pdf. Accessed August 31, 2020.

17. Department of Homeland Security $v$ Regents of The University of California, 140 S. Ct. 1891 (2020).

18. United States $v$ Texas, 136 S. Ct. 2271 (2016)

19. Title VII of the Civil Rights Act of 1964, 42 U.S.C $\$ 2000 \mathrm{e}-2(\mathrm{a})(1)$

20. Bostock v Clayton County, 140 S. Ct. 1731, 1741 (2020).

21. Brief of the American Medical Association, the American College of Physicians, and 14 additional medical, mental health, and health care organizations as Amici Curiae In Support of the Employees, Bostock $v$ Clayton County. July 3, 2019. https://www.supremecourt.gov /DocketPDF/17/17-1618/107177/20190703172548842 _Amicus\%20Brief.pdf. Accessed August 31, 2020.

22. Our Lady of Guadalupe School v Morrissey-Berru, 140 S. Ct. 2049 (2020).

23. United States Leadership Against HIV/AIDS, Tuberculosis, and Malaria Act ("the Leadership Act"), 22 U. S. C. $\$ 7601$ et seq

24. Agency for International Development $v$ Alliance for Open Society, 140 S. Ct. 2082, 2086 (2020).

25. 42 U.S.C. $\$ 1342, \$ 18063$.

26. Maine Community Health Options v United States, $140 \mathrm{~S}$. Ct. $1308(2020)$.

27. Hague Convention on the Civil Aspects of International Child Abduction (Hague Convention or Convention), implemented in the United States by the International Child Abduction Remedies Act, 22 U. S. C. $\$ 9001$ et seq.

28. Monasky v Taglieri, 140 S. Ct. 719 (2020).

29. Monasky v Taglieri, 140 S. Ct. 719, 723, 729 (2020)

30. Feldman A. Final stat pack for October term 2019 (upated). July 10, 2020. https://www.scotusblog.com/2020/07/final-statpack-for-october-term-2019/. Accessed August 31, 2020.

31. Hejmanowski D. Flush heard around the world. Delaware Gazette. May 8, 2020. https://www.delgazette.com/opinion /columns/83610/flush-heard-around-the-world. Accessed August 31, 2020.

32. SCOTUSblog.com. California $v$ Texas. https://www .scotusblog.com/case-files/cases/california-v-texas/. Accessed August 31, 2020 